\title{
MORPHOMETRIC AND BIOMECHANICAL PARAMETERS OF TIBIOTARSUS IN DIFFERENT STRAINS OF BROILERS **
}

\author{
D. Vitorović ${ }^{*}$, Z. Pavlovski ${ }^{2}$, Z. Škrbić ${ }^{2}$, M. Lukić ${ }^{2,}$ V. Petričević ${ }^{2}$ \\ ${ }^{1}$ Faculty of Agriculture, 11080 Zemun \\ ${ }^{2}$ Institute for Animal Husbandry, Belgrade-Zemun, 11080 Zemun \\ * Corresponding author: Dušan Vitorović, e-mail: \\ **Original scientific paper - Originalni naučni rad \\ Research was financed by the Ministry of Science of Republic of Serbia within project TR 20021 \\ - Rad je finansiran od strane Ministarstva za nauku Republike Srbije u okviru projekta TR 20021
}

\begin{abstract}
One hundred male and one hundred female broiler chicks from different strains : Master Gris, Red Bro, Farm Q and Hubbard Classic, were reared in conventional broler house system, during first three weeks After the third week, fattening was continued in an extensive free-range rering system. At the end of experimental period (91 days of age) 10 male and 10 female birds, of each stran, were killed by cervical dislocation and the right tibiotarsal bones were removed and used for morphological and mechanical analysis.

The obtained results showed that there were statistically signifficant strain differences. Mass, length, breaking force, cross sectional area of diaphysis, medullary cavity area and cortical area, of tibiotarsal bone of Farm Q hybrid chicks were statistically signifficant lower than that of Hubbard Classic, Master Gris and Red Bro strains in both male and female chicks.
\end{abstract}

Key words: Broilers, strain, tibiotarsus, morphometry, mechanics

\section{Introduction and literature review}

Selection pressure for broilers with larger breast meat resulted in an increase in leg problems (Nestor and Emmerson, 1990; Lilburn, 1994; Julian, 1998). Skeletal problems compromise the birds welfae. They also reduce growth, increase mortality and are recognised as one of four major factors affecting the performance of broilers (Day, 1990). Market age poultry often suffer from lameness and bone deformities, which can cause bone breakage during catching and transportation and which create problem during processing 
(Gregory and Wilkins, 1992; Knowles and Wilkins, 1998). Different methods were used for bone quality assey: bone strength, cross-sectional geometry of long bones and chemical composition of asch (Vitorović, 1992; Vitorović et al., 1995; Cubo and Casinas, 1998; Skrbic, 2007). There are many factors influencing bone quality in broilers. They include a variety of nutritional disorders, infectious diseases, metabolic conditions and toxins (Riddel et al., 1983; Thorp, 1994; Rath et al., 2000). Many of bone disorders have both genetic and nutritional factors controling their incidence and severity. There are a little reports describing the strain effects on the morphology or mechanical characteristics of broilers bones (Kestin and Sorensen, 1999; Yacin et al., 2001). Over the past decade meat-type chickens have been genetically selected for improving skeletal quality in additioin to growth performance (Williams et al., 2000).

The purpose of this study was to estimate the effects of strain on orphological and mechanical properties of tiobiotarsal bone in male and female broiler chickens, aged 91 days.

\section{Material and methods}

The experiment was performed on 100 male and 100 female broiler chicks from different strains : Master Gris, Red Bro, Farm Q and Hubbard Classic. The birds were reared in conventional broler house system, during first three weeks, with controled standard ambiental conditions (feeding, light, temperature). After the third week, fattening was continued in an extensive freerange rering system. Only, during the night the birds were kept in a house. They were feed grains (corn, wheat and oats) and they also acquire feed by foraging in the backyard. At the end of experimental period (91 days of age) 10 male and 10 female birds, of each stran, were killed by cervical dislocation and the right tibiotarsal bones were removed and used for morphological and mechanical analysis.

The wet bone weight, proximo-distal length and outer diameters (antero-posterior and latero-medial) were measured at the middle of diaphysis. After that, bone breaking force was measured by three-point- bending test, using IPNIS aparatus (Mašić and Pavlovski, 1994). At the middiaphyseal transverse section of each bones, the interior diameters (antero-posterior and latero-medial) were measured. On the basis of the data obtained of outside and interior diameters, the cross sectional diaphyseal area, cross sectional medullary area and cross sectional cortical area of tibiotarsus were calculated, according to Vitorović (1992). 
Data for all bone parameters were subjected to Analysis of Variance and differences between the strains were tested by Tukey HSD test, using Stat Soft, Inc (2003), STATISTICA (data analysis software system), version 6.

\section{Results and discussion}

In table 1, results of the measuring of morphometric and mechanical properties of tibiotarsus of male broilers of different strains at the age of 91 days, are presented. In regard to the mass and length of tibiotarsus it was established that Master Gris chickens have statistically considerably $(p<0,01$; $\mathrm{p}<0,05$ ) higher values in relation to chickens of Farm $\mathrm{Q}$ strain. Between other strains the presence of significant differences wasn't established. Bone breaking force in chickens of Hubbard Classic strain $(29,0 \mathrm{~kg})$ was statistically highly significantly $(p<0,01)$ higher, and in chickens of Master Gris strain $(27,7)$ significantly $(p<0,05)$ higher compared to breaking force of tibiotarsus tibiotarsus in chickens of Farm Q strain $(25,8 \mathrm{~kg})$. Similar conclusions were made also for geometrical properties of the tibiotarsus diaphysis cross section. The lowest values of the cross sectional diaphyseal area, cross sectional medullary area and cortical area were recorded in chickens of Farm Q strain. They were statistically significantly lower compared to values measured on tibias of other three strains.

Table 1. Morphometric and biomechanical parameteres of tibiotarsus of male broilers, various strains, at 13 weeks of age

Tabela 1. Morfometrijske i biomehaničke osobine golenjače muških pilića različitih hibrida, u uzrastu od 13 nedelja

\begin{tabular}{|l|c|c|c|c|}
\hline \multirow{2}{*}{$\begin{array}{l}\text { Parameter of bone/ } \\
\text { Osobine kosti }\end{array}$} & \multicolumn{4}{|c|}{ Strain/Hibrid } \\
\cline { 2 - 5 } & Farm Q & Hubbard Classic & Master Gris & Red Bro \\
\hline Mass/Masa, g & $26,4 \pm 3,0$ & $33,0 \pm 4,1$ & $38,8 \pm 4,1^{* *}$ & $33,0 \pm 5,8$ \\
\hline Length/Dužina, cm & $12,5 \pm 0,5$ & $12,3 \pm 0,4$ & $3,6 \pm 0,4^{*}$ & $13,1 \pm 0,5$ \\
\hline Breaking force/Sila loma, kg & $25,8 \pm 1,4$ & $29,0 \pm 6,8^{* *}$ & $27,7 \pm 4,5^{*}$ & $26,5 \pm 5,9$ \\
\hline $\begin{array}{l}\text { Cross sectional diaphyseal } \\
\text { area/Poprečni presek } \\
\text { dijafiye, mm }\end{array}$ & $49,3 \pm 2,2$ & $65,4 \pm 7,9^{*}$ & $73,7 \pm 8,1^{* *}$ & $63,4 \pm 7,9^{*}$ \\
\hline $\begin{array}{l}\text { Cross sectional medullary } \\
\text { area/Poprečni presek } \\
\text { medularne šupljine, mm }\end{array}$ & $30,6 \pm 2,3$ & $38,3 \pm 4,7$ & $49,5 \pm 6,8^{*}$ & $36,2 \pm 6,5$ \\
\hline $\begin{array}{l}\text { Cross sectional cortical } \\
\text { area/Površina korteksa, } \\
\text { mm }\end{array}$ & $18,7 \pm 1,6$ & $27,1 \pm 3,5^{*}$ & $24,2 \pm 5,2$ & $27,2 \pm 5,4^{*}$ \\
\hline
\end{tabular}


Mean \pm Standard deviation; Singifficance of differences : ${ }^{*}-\mathrm{p}<0,05 ;{ }^{* *}-\mathrm{p}<0,01$

Srednja vrednost \pm Standardno odstupanje; Značajnost razlika : ${ }^{*}-\mathrm{p}<0,05 ;{ }^{* *}-\mathrm{p}<0,01$

In table 2 results of the measuring of morphometric and mechanical properties of tibia in female chickens of different strains are presented.

Similar conclusions are made like for male chickens. Female chickens of Farm Q strain had tibias with masses, lengths, breaking forces and cross sectional areas which were statistically significantly lower compared to values measured in strains Hubbard Classic, Master Gris and Red Bro. Presence of statistically signifcant differences in morphometric and mechanical properties of tibia.

Table 2. Morphometric and biomechanical parameteres of tibiotarsus of female broilers, various strains, at 13 weeks of age

Tabela 2. Morfometrijske i biomehaničke osobine golenjače ženskih pilića različitih hibrida, u uzrastu od 13 nedelja

\begin{tabular}{|l|c|c|c|c|}
\hline \multirow{2}{*}{$\begin{array}{l}\text { Parameter of bone/ } \\
\text { Osobine kosti }\end{array}$} & \multicolumn{4}{|c|}{ Strain } \\
\cline { 2 - 5 } & Farm Q & Hubbard Classic & Master Gris & Red Bro \\
\hline Mass/Masa, g & $19,3 \pm 3,1$ & $25,9 \pm 2,8^{*}$ & $26,5 \pm 5,5^{*}$ & $26,4 \pm 3,4^{*}$ \\
\hline Length/Dužina, cm & $11,6 \pm 0,4$ & $11,8 \pm 0,7$ & $12,8 \pm 0,9^{*}$ & $12,2 \pm 0,3$ \\
\hline $\begin{array}{l}\text { Breaking force/Sila loma, } \\
\text { kg }\end{array}$ & $19,8 \pm 3,6$ & $26,5 \pm 6,9^{* *}$ & $24,7 \pm 5,7^{*}$ & $23,6 \pm 7,3$ \\
\hline $\begin{array}{l}\text { Cross sectional diaphyseal } \\
\text { area/Poprečni presek } \\
\text { dijafiye, mm }\end{array}$ & $41,8 \pm 3,2$ & $56,0 \pm 5,7^{*}$ & $57,9 \pm 7,1^{*}$ & $49,6 \pm 7,3$ \\
\hline $\begin{array}{l}\text { Cross sectional medullary } \\
\text { area/Poprečni presek } \\
\text { medularne šupljine, mm }\end{array}$ & $26,7 \pm 2,5$ & $30,4 \pm 4,2$ & $35,7 \pm 4,8$ & $27,2 \pm 5,5$ \\
\hline $\begin{array}{l}\text { Cross sectional cortical } \\
\text { area/Površina korteksa, } \\
\text { mm }\end{array}$ & $14,9 \pm 1,6$ & $27,1 \pm 3,5^{* *}$ & $24,2 \pm 5,2^{*}$ & $27,2 \pm 5,4^{* *}$ \\
\hline
\end{tabular}

Mean \pm Standard deviation; Singifficance of differences : ${ }^{*}-\mathrm{p}<0,05 ; * *-p<0,01$

Srednja vrednost \pm Standardno odstupanje; Značajnost razlika : ${ }^{*}-\mathrm{p}<0,05 ;{ }^{* *}-\mathrm{p}<0,01$ 


\section{Conclusion}

Based on carried out measurings the following can be concluded:

- The effect of strain on morphometric and biomechanic traits of tibia in broiler chickens is present

- Chickens of Farm Q strain had tibias whose mass, length, breaking force and cross sections of diaphyseal area, medullar area and cortex, were statistically significantly lower compared to chickens of Hubbard Classic, Master Gris and Red Bro strain.

- The stated differences are present in male and female chickens.

\section{Morfometrijske i biomehaničke osobine golenjače različitih hibrida brojlera}

D. Vitorović, Z. Pavlovski, Z. Škrbić, M. Lukić, V. Petričević

\section{Rezime}

Po 100 muških i 100 ženskih pilića hibrida Master Gris, Red Bro, Hubbard Classic i Farm Q, je, tokom prve tri nedelje tova, gajeno u zatvorenim objektima sa standardnim uslovima ishrane, napajanja i ambijenta. Posle treće nedelje, pilići su prebačeni u ekstenzivni sistem gajenja sa ispustima. Tov je trajao 91 dana, kada je izvršeno žrtvovanje životinja. Od po 10 jedinki muškog i ženskog pola, svakog hibrida, uzimana je desna golenjača za morfometrijska i biomehanička ispitivanja.

Dobijeni rezultati su pokazali da između hibrida postoje značajne razlike u osbinama golenjače. Msa, dužina, sila loma i poprečni presci dijafize golenjače, medularne šupljine i površina preseka korteksa, golenjače hibrida Farm Q, bili su statistički značajno manji u odnosu na ostala tri hibrida. Ove razlike su se ispoljile i kod pilića muškog i kod pilića ženskog pola.

Ključne reči: brojleri, golenjača, hibrid, morfometrija, čvrstoća 


\section{References}

CUBO J., CASINOS A. (1998): Biomechanical significance of cross-sectional geometry of avian long bones. European Journal of Morpholgy, vol. 36, No.1, 19-28.

DAY E., (1990): Future research needs focus on new, old problems. Feedstuffs, 23, 12-15.

GREGORY N., C., WILKINS L., J. (1992): Skeletal damage and bone defects during catching and processing. Bone Biology and Skeletal Disorders in Poultry., Carfax Publishing Co., Oxford UK., 313-328.

JULIAN R., J. (1998): Rapid growth problems: ascites and skeletal deformities in broilers. Poult. Sci., 77: 1773-1780.

KESTIN C., S., SORENSEN P. (1999): Different commercial broiler crosses have different susceptibilities to leg weaknes. Poult. Sci., 78: 1085-1090.

KNOWLES T., G., WILKINS L.,J. (1998): The problems of broken bones during handling of laying hens - rewiew. Poult. Sci., 77:1798-1802.

LILBURN M., S. (1994): Skeletal growth of commercial poultry species. Poult. Sci., 73: 897-903.

MASIC B., PAVLOVSKI Z., (1995): Dostignuca i perspektiva selekcije kokosI brojlerskog tipa. Biotehnlogija u stocarstvu, 11, 47-53.

NESTOR K., E., EMMERSON A., D., (1990): Role of genetics in expression and prevention of leg weakness. Proceeding of the Avian Skeletal Disease Symposium,, San Antonio, 14-21.

RATH C., N., HUFF R., G., HUFF E., W., BALOG M.J. (2000): Factors regulating bone maturity and strength in poultry. Poult. Sci., 78, 1024-1032.

RIDDEL C., KING M.W., GUNAESEKERA K.,R. (1983): Pat5hology of the skeleton and tendons of broiler chickens reared to roaster weight. II . Normal chicken. Avian Diseases, 27: 980-991.

SKRBIC Z., (2007): Effekti gustine naseljenosti i svetlosnog programa na proiyvodne I klanicne osobine brojlerskih pilica razlicitog genotipa. Doktorska disertacija, Poljoprivredni fakultet, Beogra.

THRP B. H. (1994): Skeletal disorders in the fowl: A rewiew. Avian pathology, 23, 203-236.

VITOROVIC D. (1992) Anatomske karakteristike kostiju i misica pilica lakog i teskog tipa gajenih na podu i u kavezma. Doktorska disertacija, veterinarski fakultet, Beograd.

VITOROVIC D., POPOV RALJIC J., MITROVIC S. (1995) The effect of age and rering system on bone strength of broiler chicks., Biotehnologija u stocarstvu, 11 (1-2), 21-26. 
WILLIAMS B., SOLOMON S., WADDINGTON D., THORP B., FARQUHARSON C. (2000): Skeletal development in meat-type chicken. British Poultry Science, 41, 141-149.

YALCIN S., OZKAN S., COSKUNER E., BILGEN G., DELEN Y., KURTULUMUS Y., TANYALCIN T. (2001): Effects of strain, maternal age and sex on morphological characteristics and composition of tibial bone in broilers. British Poultry Science, 42,2, 184-190. 